\title{
Industrial Conflict Resolution using Court-connected Alternative Dispute Resolution
}

\author{
Oyesola Animashaun
}

Kola O. Odeku

\author{
Faculty of Management and Law, University of Limpopo, Turfloop, South Africa
}

\author{
Doi:10.5901/mjss.2014.v5n16p683
}

\begin{abstract}
Conflict is inevitable in any human relationship but the ability to resolve dispute and conflict amicably and expeditiously under the law is one of the distinguishing factors between a civilized society and a primitive one. The lack of an independent judiciary and well defined conflict resolution mechanism is a feature of a failed state and an indicator of under development. In any modern society, the court is vested with judicial powers. The traditional modus operandi is litigation which is essentially adversarial and confrontational. It is also bedevilled with inordinate delays, technicalities, procedural and evidential rules and high cost of litigation. Most times, justice is not served and this often led to distrust of the legal system on the part of the litigants who may resort to self-help or self-denial. The Alternative Dispute Resolution (ADR) mechanism was introduced into the Nigerian legal system in the quest for speedy and amicable resolution of conflict. The usefulness of ADR in the settlement of workplace related conflicts need not be over emphasised, as the whole world is inter connected and now a global village. Speedy resolution of conflict in industrial and commercial matters in any polity is a comparative advantage for such polity in international trade. This treatise shall look at the concept of court connected ADR in resolving conflict with special emphasis in the workplace, its usefulness, or otherwise practises in other jurisdictions and make appropriate recommendations.
\end{abstract}

Keywords: Alternative dispute resolution, conflict, dispute, arbitration, adjudication, mediation.

\section{Introduction}

In any transaction, there could be disagreement as a result of misunderstanding by the parties for one reason or another (Botha, 2000). However, what is important is that the parties should be able to find a common ground and resolve the dispute (Kotze, 2012). Informal amicable resolution of dispute is therefore highly prescribed as opposed to formal, strict judicially entrenched way of resolving dispute (Gibbons, 2007). In any human endeavour or dealings, a lot of reasons might trigger disputes, particularly in commercial transactions such as misunderstandings which might arise because of poor communication, it could be differences in the way and manner parties perceive issues and their moral and value judgments, the expertise and skill possessed by each party could also be reason for conflict, also people often have unrealistic expectations and this may cause rift and conflict if it is not fulfilled (Adler, 2005). For an example, the client wants speedy completion and a quality product at a low price (Schrage, 2013). The contractor may want more time, a more reasonable quality and maximum price (Egemen and Mohamed, 2006) At this point in time, an element of conflict has been already introduced because the parties have parallel expectations (Thompson, 2011). The situation is already stressed up and undoubtedly this is a sign for prospective dispute. At an individual level, disagreements and conflicts may occur in transactions as a result of factors such as languages, dynamics, geography, childhood experiences, upbringing and religion; Education levels, both structured and unstructured learning can have an influence on conflict ( Dani, 2005.). Differences in one or two projects to be handled and performed could also be sources of conflicts among the parties (Moore, 2014). In most transactions, and sometimes from one project to the next there could be different building teams, different financiers and different designers; changes to plans, deadlines, payment dates, and so on, all these can cause disputes (Jacobson and Choi, 2008). Nature and extreme weather events could also be a factor and trigger dispute,( Mitchell et al. 2014) dispute could arise due to the delay caused by the weather, a sub contractor, the bank or a third party; parties often inadequately define quality ( Aibinu and Odeyinka, 2006). High quality may mean different things to a plasterer and to the project director or project manager ( Ozorhon et al. 2010). Against the backdrop of all these dynamics, one needs to use objective standards to define materials and workmanship (Harris and McCaffer, 2013). In order to avert dispute, from the inception, one must precisely and clearly describe what one requires from the other party and what is expected from the project being undertaken (Yates and Epstein, 2006). A client may specify a much higher standard than what he really wants while wanting a lower price and so on (lacobucci and Churchill, 2009). Adejumo 
(2011) posited that "workplace conflict in Nigeria may be due to any or a combination of the following: the absence of National Labour Policy; lack of respect for the terms of collective agreements reached between employers and employees; frequent recourse to industrial action such as strike by labour union; inadequate labour law; lack of skilled manpower by the regulatory agencies and institutions; lack of discipline and honesty on the part of the leadership of the labour union and administrators alike (allegation of non- remittance of check off dues, sit tight leadership, lack of accountability, dictatorial tendencies); poor labour inspection culture." When such dispute arises it is ideal that it is resolved promptly, at reasonable cost with a view to continue the existing relationship (Bingham, 2004).

It behoves on the judiciary to resolve disputes and conflict in the society but more essentially by way of informal alternative (AAA, 2010). One of the pillars that hold the fort of the state is the judiciary (Baldock, 1997). Speedy, efficient and fair dispensation of justice is a sine qua non for a stable, just and developed (or developing) society (Angaye and Gwilliam, 2009). Actually, it was regarded as the last hope of the common man in Nigeria (Afe, 2013). This made Gladstone, commenting on the British experience to state that 'National injustice is the surest road to national downfall.' The judiciary should serve as the institution that rescues the citizens from the recklessness and arbitrariness of the executives and the lawlessness of the legislature (Tarr, 2012). In Nigeria, the reputation of the judiciary has however been tainted with corruption (Eso, 2005), resulting in undue long delays in rendering verdict. (For examples, the case of Wakino v Ade John (1999) 9 NWLR (pt.619) p. 403 took 11 years in the high court due to series of adjournment., Lasisi Atanda V Ajani (1989) 3 NWLR 511 took 10 years to reach the Supreme Court which ordered a trial de novo:,after 18 years the supreme court ordered a trial de novo of Ugo V Chukwu Obikwe (1989) 1 NWLR 566. R. Ariori \& ors V Elemo \& Ors (1983) SC NLR 1 took twenty two years (22) years to reach the apex court Supreme Court, which ordered a trial de novo by the High Court. High handedness of judges, interference from the executive. (This is well documented in the saga of Justice Salami, 2012) and similar vices have contributed in no small measure to make the cost of litigation prohibitive, time consuming and emotionally traumatising. This has made citizens to either forgo their rights or resort to self-help. In the quest to decongest the court, re-invent the judicial system and ease commercial transactions, among other things, the Nigerian state has introduced the court connected Alternative Dispute Resolution (ADR). The idea of ADR is not foreign to the Nigerian traditional system (Agu v lkewibe (1991 3 NWLR (pt 180)385; Ohiaeri v Akabeze (1993) 2 NWLR (pt 221); Okere v Nwoke (1991) 8 NWLR; Awosile v Sotunbo 19925 NWLR (pt 243) 514; Ojibah v Ojibah 1991 5NWLR (pt 191) 296;). The challenge is the carrying out of this function which is hampered by the growing cosmopolitanism of the hitherto indigenous and homogenous society, corruption and the dwindling respect for the traditional institutions (Mittelman, 2010).

\section{The Concept of ADR}

Pretorius (1993) looks at dispute resolution from the perspectives that involve dispute resolution processes involving private decision-making by the parties themselves that includes negotiation and mediation; dispute resolution processes involving private adjudication by third parties and arbitration which include dispute resolution processes involving adjudication by public authority, administrative decision-making and formal litigation before the courts.

ADR also includes practices, techniques and approaches for resolving and managing conflicts short of, or alternative to, full-scale court process (ADPG, 1998). The variety of ADR models found in developed and developing countries may be described in two fundamental ways: basic ADR processes, (Osi, 2008) which include negotiation, conciliation, mediation, and arbitration; and hybrid ADR processes, in which specific elements of the basic processes have been combined to create a wide variety of ADR methods (Fiadjoe, 2013). (For instance, mediation is combined with arbitration in med-arb) (de Vera, 2004). Hybrid ADR processes may also incorporate features found in court-based adjudication; for example, the mini trial mixes an adjudication-like presentation of arguments and proofs with negotiation (Trinder and Kellett, 2007).

\subsection{Court-connected ADR}

These are ADR processes that are linked formally to the governmental justice system; such ADR activities are authorized, offered, used, referred by, or based in the court system (Hensler, 2003). Court-based programs and court referrals to private ADR services are covered by this term (Weston, 2003). Agreements arising out of court-connected ADR may be enforceable as court orders (Welsh, 2004).

Facilitation simply refers to a process by which a neutral third-party helps the parties reach consensus on disputed issues (Sai-On and Suen, 2002). It is important to point out that while a mediator is a facilitator; an arbitrator is not (Cheldelin, 2003). With regard to impartiality/neutrality, when discussing the third party intervener, impartiality refers to 
the third party's disinterestedness in the dispute- s/he has no personal stake or interest (financial or otherwise) in the situation (Menkel-Meadow, 2001). On the other hand, a neutral third party has no inclination one way or another regarding the dispute or the disputants. It may be said that finding an impartial third party is easier than finding a neutral one (Riskin, 1997).

Mandatory/voluntary ADR approaches refer to how disputes enter ADR processes. If the parties are compelled to use ADR (by the court or statute, for example), then the use is mandatory (Sherwyn et al. 2002). If the use is based wholly on the consent of all the parties, then it is voluntary (Sherwyn, 2003).

Nonbinding/Binding are situations where the disputants are required to accept and respect the outcome of the ADR process, such as third party opinions, that process is binding (Devereaux, 2006). ADR outcomes that are advisory only are a feature of nonbinding processes (Chappe, 2013). As a rule, disputants are not bound by an outcome or resolution in ADR, unless they agree to be bound (Hensler, 2003). In spite of this, it is pertinent to point out that there are exceptional situations of mandatory binding arbitration especially when prescribed by statutes and laws (Sheppard, 2007).

\subsection{Basic ADR Models and Definitions}

Negotiation is the most common form of dispute resolution, negotiation is the process by which the parties voluntarily seek a mutually acceptable agreement to resolve their common dispute (Moore, 2014.). Compared with processes involving third parties, generally negotiation allows the disputants themselves to control the process and the solution (Pruitt, 2005). Examples are Nicaragua-negotiation training (Lytton et al. 1998); South Africa-negotiation of community disputes; Indonesia- environmental conflict (Moore and Santosa, 1995).

Conciliation is a process in which a third party meets with the disputants separately in an effort to establish mutual understanding of the underlying causes of the dispute and thereby promote settlement in a friendly, un antagonistic manner (Agbu et al. 2006). Often the first step, and at times sufficient, to resolve disputes. Examples are South Africa Case Study - Commission for Conciliation, Mediation, and Arbitration; Bolivia Case Study; Colombia - Bogota Chamber of Commerce centres (DPK Consulting, 1994); U.S.A.-historically used in some labour disputes as a step prior to arbitration; India - People's Courts (Whitson, 1992); Japan - auto accident victims and insurance companies (Moriya, 1997).

Mediation is a voluntary and informal process in which the disputing parties select a neutral third party (one or more individuals) to assist them in reaching a mutually-acceptable settlement (Moore, 2014). Unlike a judge or arbitrator, the mediator has no power to impose a solution on the disputants; instead, the mediator assists them in shaping solutions to meet their interests. The mediator's role and the mediation process may vary significantly, depending on the type of dispute and mediator's approach (Bercovitch and Gartner, 2006). Mediators can employ a wide-range of techniques, for example, assist parties to communicate effectively and develop a cooperative, problem-solving attitude; identify parties' underlying interests; identify and narrow issues; transmit messages between parties; explore possible options for agreement and the consequences of non-settlement (Abramson, 2004). Examples are South Africa-Independent Mediation Service of South Africa (IMSSA), victim-offender mediation; Sri Lanka-Mediation Boards; Indonesiaenvironmental disputes (Moore); Malaysia - inter-ethnic disputes (Othman, 1996), India-civil and criminal cases (Kassebaum, 1989); USA - community mediation (McGillis, 1997), mandatory civil case mediation in North Carolina (Clarke, 1995); Bangladesh Case-community mediation based on indigenous practice.

Arbitration is an adjudicatory dispute resolution process in which one or more arbitrator's judge issues on the merits (which may be binding or non-binding) after an expedited, adversarial hearing, in which each party has the opportunity to present proofs and arguments (Stong, 2009). Arbitration is procedurally less formal than court adjudication; procedural rules and substantive law may be set by the parties (Hollander-Blumoff and Tyler, 2011).

In court-annexed arbitration, one or more arbitrators, usually lawyers, issue a non-binding judgment on the merits after an expedited, adversarial hearing (Sherman, 1992). The arbitrator's decision addresses only the disputed legal issues and applies legal standards (Getman, 1979). Either party may reject the non-binding ruling and proceed to trial; sometimes, cost sanctions may be imposed in the event the appellant does not improve his/her position in court. This process may be mandatory or voluntary. Examples are USA- used in federal and state courts, mainly in small and moderate-sized tort and contract cases, where the costs of litigation are often much greater than the amounts at stake; Japan - appellate ADR (Iwai, 1991). Private-court-annexed arbitration may be administered and managed by private organizations, or non-administered and managed by the parties (Reilly and MacKenzie, 1999). The decisions of arbitrators in private arbitration may be non-binding or binding (Sternlight, 2007). Binding arbitration decisions typically are enforceable by courts and not subject to appellate review, except in the cases of fraud or other defect in the process (Janicke, 2002). Often binding arbitration arises from contract clauses providing for final and binding arbitration as the 
method for resolving disputes ( Jannadia et al. 2000). Examples are South Africa Case- IMSSA; and Thailandcommercial arbitration (Worawattanamateekul, 1996).

\subsection{Examples of Hybrid ADR Models}

A wide variety of hybrid models have emerged in developed and developing countries. Below are some examples of hybrids found connected to courts in commercial and government settings.

In an Appellate ADR, appellate court programs use mediation in mandatory and pre-argument conferences in cases that appear most easy to settle; mediators are typically staff attorneys or outside lawyers (Wissler, 2004). Example: USA-common in federal and state appeals courts.

Early Neutral Evaluation (ENE) is a court-based ADR process applied to civil cases, ENE brings parties and their lawyers together early in the pre-trial phase to present summaries of their cases and receive a nonbinding assessment by an experienced, neutral attorney with expertise in the substance of the dispute, or by a magistrate judge (McEwen, 1998). The evaluator may also provide case planning guidance and settlement assistance. In some courts, it is used purely as a settlement device and resembles evaluative mediation (Wahab, 2013). Example is found in: USA-developed during the mid-1980s in the San Francisco federal court. ENE is now used in the U.S. in state and federal courts.

Fact-Finding is a process by which a third party renders binding or advisory opinions regarding facts relevant to a dispute (Smith and Martinez, 2009). The neutral third party may be an expert on technical or legal questions, may be representatives designated by the parties to work together, or may be appointed by the court (Wetsch, 2000).

Judge-Hosted Settlement Conference is a court-based ADR process where the settlement judge (or magistrate) presides over a meeting of the parties in an effort to help them reach a settlement. Judges have played a variety of roles in such conferences, articulating opinions about the merits of the case, facilitating the trading of settlement offers, and sometimes acting as a mediator (Zimmer, 2011). This is the most common form of ADR used in US federal and state courts; Japan-judge as neutral may implement three ADR procedures (Jardine, 1996) Med-Arb., or Mediation-Arbitration is an example of multi-step ADR, parties agree to mediate their dispute with the understanding that any issues not settled by mediation will be resolved by arbitration, using the same individual to act as both mediator and arbitrator (Blankley, 2011). Having the same individual act in both roles, however, may have a chilling effect on the parties participating fully in mediation (Coben and Thompson, 2006). They might believe that the arbitrator will not be able to set aside unfavourable information learned during the previous mediation (Singer et al. 1992).

\section{Advantages of ADR}

The followings are the advantages that ADR has over litigation:

Reducing the cost to parties: Many poor people cannot access the formal legal system because they cannot afford to pay the registration and representation fees necessary to prosecute cases in the courts (McFarland, 2004). This is because payment of legal fees is probably the largest barrier to formal dispute resolutions for many people in developing countries and in particular by the poor in Nigeria (CLEP, 2008).

Reducing the formality of the legal process: Several studies indicate that the formality of court systems intimidates and discourages use (Leon, 2005). In India and Bangladesh, for example, the court requirement of legal representation is both costly and intimidating for people who may not be comfortable interacting with lawyers from a different caste or class (Sowell, 2004). Thus, users of ADR programs in many countries have expressed a preference for submitting cases to mediators who are local residents and understand the local community (Cohen, 2006). In Sri Lanka, users expressed their satisfaction at having their stories heard in an informal process. All these factors contribute to greater usage of and preference for informal processes.

Overcoming the barrier of illiteracy: In some countries, access to formal system is denied as a level of literacy that many in the country do not possess is required. In these countries, the formal legal processes are especially intimidating for large numbers of illiterate citizens ( Watson, 2007). In Bangladesh, the Madaripur Legal Aid Association was originally established to provide assistance and representation for the poor and illiterate (Ahmed and Islam, 2013). Their services are now dominated by their mediation program, in part because they found mediation to be more effective and accessible for this part of the population (Muralidhar, 2005). ADR programs can be designed to rely on oral representations. Oral agreements may be enforced by traditional means of community peer pressure, eliminating the need for written documentation or formal enforcement mechanisms (Moore, 2014).

Serving rural populations and geographically dispersed locations: Access may be impaired as the courts are located far from the homes of those who need them. One advantage of ADR programs is the ability to set them up with 
relatively little cost to local communities (Shepard, 2011). The lok adalat ("people's court") system in India succeeded in reaching a large part of the population because they were located in villages (Whitson, 1992). Similarly, the Mediation Boards in Sri Lanka are distributed throughout rural villages, as well as larger cities and towns. In China, more than one million People's Mediation Centres are located in villages and serve parts of the population that could not easily reach existing courts (Jandt and Pederson, 1996).

Counteracting discrimination and bias in the system When courts are systematically biased against particular groups, such as minorities or women, ADR programs can sometimes help provide some measure of justice (Golub, 2003). In Bangladesh, for example, women are often poorly protected by the courts (Ahmad, 2002). The MLAA mediation program has recruited women to serve on mediation panels in the village mediation program (Goresh, 2008). Women who have used the system believe that they receive better protection and more compensation from this system than from the formal court system (Dey, 2009).

In many circumstances, however, ADR will not improve access for discrimination against populations and may, some argue, even worsen their situation (Roberts and Palmer, 2005). Informal dispute resolution services may offer "second-class" justice to users, particularly minorities and women who may be subject to bias in ADR programs as well as in the formal judicial system (Justice, 2006). Informal dispute resolution systems are ineffective at changing policy and systemic injustices since they deal with individual cases and do not establish legal precedent (Whitson, 1992). In Bangladesh, the ADR program design is able to address the issue of bias through recruitment of minority mediators and thorough training ( Van Rooij, 2012). Through this, justice can be improved for these disadvantaged groups.

\section{Multi Door Courthouse in Nigeria}

The Lagos State Judiciary established The Lagos Multi-Door Courthouse (LMDC) as the first court-connected ADR centre in Africa (Onyema, 2013). Subsequently, the concept was replicated in the judiciary of Abuja and presently, at least thirteen judiciaries in Nigeria have shown interest in its replication. The overriding objective of the MDC is as contained in the Lagos Multi-Door Courthouse Practice Direction namely to "enlarge resources for justice by providing enhanced, timely cost-effective and user-friendly Access to Justice for would be and existing plaintiffs and defendants." Hence, instead of litigation being the "mono-door" for the resolution of disputes, the MDC has three supplementary doors by which disputes can be resolved, namely; early neutral evaluation, mediation and arbitration.

\subsection{The Concept of MDC and How It Operates}

The key feature of the MDC proceedings is the initial procedure, which is in two stages:

\subsubsection{Intake Screening and Referral and Intake Screening}

Upon the receipt of the disputing parties' Statement of Issues, the ADR Registrar shall exchange the Statements between the parties and invite them for a preliminary meeting or screening. An Individual Screening Conference is set up for appropriate cases. This provides a unique opportunity for individual cases that need assessment and litigation/ADR management. This is the hallmark of the Lagos Multi Door Courthouse (LMDC). Experienced multi-door courthouse staff conduct it. It is confidential, with no report made on the court file or to the judge assigned to the case. The confidentiality is protected by statute and promotes frank discussion of both legal and non-legal issues. The tone of a screening conference usually differs substantially from status or pre-trial conferences in court. In the latter, participants tend to be less candid and to maintain their adversarial posture by developing, building and maintaining their positions. The Screening Conference on the other hand, is directed towards information exchange with the goal of problem-solving and dispute resolution. The process is designed to involve the participants in assessing their case needs from a practical perspective. There are four fundamental components: introduction to the programme and education of the participants in dispute resolution processes; the gathering of information, including the case facts, procedural history, legal issues, and subjective factors that may impact on the case; the identification of impediments to resolution; and matching the case with an appropriate ADR process and neutral.

The education component continues to play an important role in identifying how different processes may be useful in a particular case, although many lawyers have become much more

Sophisticated about ADR and have greater understanding of its importance. For those unfamiliar with the multidoor courthouse, the screening process begins with an explanation of the programme and a review of the protocol 
including confidentiality.

\section{Conclusion}

The treatise has shown that ADR embraces conciliation, mediation and arbitration process of dispute resolution. The most appropriate type or form of ADR for a particular case depends upon the needs of the parties in the dispute. In some cases, ADR has advantages over litigation, but not all cases could be solved by ADR.

\section{References}

AAA 2010. AAA Handbook on Construction Arbitration and ADR. American Arbitration Association. New York, USA:JuristNet.

Abramson HI 2004 . Mediation Representation: Advocating in a Problem-Solving Process. From http://books.google.co.za/books?hl=en\&lr=\&id=7x9maioa1fuc\&oi6b5s4eychf\&sig=8ilqh9xxfzay73w6fxiqjjexieo\#v=onepage\&q\&f=f alse. (Retrieved on March 24, 2012).

Adejumo BA 2011. Building Effective Conflict Management Mechanism for Sustainable development in Nigeria being a Paper presented at the $7^{\text {th }}$ edition of the National Labour Relations Summit organised by the Micheal Imoudu National Institute For Labour Studies, llorin on Nov $17^{\text {th }} 2011$.

Adler RS 2005. Flawed Thinking: Addressing Decision Biases in Negotiation. Ohio State Journal on Dispute Resolution, 20:683-698.

ADPG 1998. Alternative Dispute Resolution Practitioner's Guide. Technical Publication Series Center for Democracy and Governance. Bureau for Global Programs, Field Support, and Research U.S. Agency for International Development Washington, D.C. 205233100.

Afe AE 2013. Insecurity in Contemporary Nigeria: Useful Lessons of Judicial Administration in the Old Ondo Province as a Panacea. From Journal of Arts and Humanities, 2013. http://www.theartsjournal.org/index.php/site/article/view/100. (Retrieved on January 4, 2014).

Agbu O, Aiyede ER, Durojaye MOB, Aiyede ER, Ofulu $\mathrm{Cl} 2006$. Theories in conflict management. From http://www.nou.edu.ng/NOUN_OCL/pdf/pdf2/PCR\%20701.pdf. (Retrieved on February 16, 2012).

Ahmad MM 2002. Who cares? The personal and professional problems of NGO fieldworkers in Bangladesh. Development in Practice, 12(2): $177-191$

Ahmed B, Islam MT 2013. The Role of Union Parishad in Rural Dispute Resolution in Bangladesh: an Evaluation in the Light of People's Perception. From http://studiesonasia.illinoisstate.edu/seriesiv/documents/ahmed_islam_studies_march2013.pdf. (Retrieved on April 29, 2014).

Aibinu AA, Odeyinka HA 2006. Construction Delays and Their Causative Factors in Nigeria. Journal of Construction Engineer Manage, 132(7): 667-677.

Angaye PEG, Gwilliam D 2009.Corporate governance in infancy and growth-an interview-based study of the development of governance and corporate regulation in Nigeria. From hhttp:emeraldinsight.com. (Retrieved on January 1, 2012).

Baldock JBR 1997. Judicial Independence: A Discussion of Judicial Independence with Judges of the United States Court of Appeals for the Tenth Circuit. From https://itigation-essentials.lexisnexis.com/webcd/app?action=DocumentDisplay\&crawlid=1\&doctype=cite \&docid=74+Denv.+U.L.+Rev.+355\&srctype=smi\&srcid=3B15\&key=8c494ffe1c0981f8307fa7fafd9a4e6f. (Retrieved on January 22, 2012).

Bercovitch J, Gartner SS 2006. Is There Method in the Madness of Mediation? Some Lessons for Mediators from Quantitative Studies of Mediation. International Interactions: Empirical and Theoretical Research in International Relations, 32(4): 329-354.

Bingham B 2004. Control over dispute-system design and mandatory commercial arbitration. From http://www.jstor.org/discover/10.2307/27592040?uid=3738032\&uid=2\&uid=4\&sid=21104445479767. (Retrieved on July 4, 2012).

Blankley K M 2011. Keeping a Secret from Yourself - Confidentiality When the Same Neutral Serves Both as Mediator and as Arbitrator in the Same Case. Baylor Law Review, 63:317-329.

Botha H 2000 Conflict in the Construction Industry. London, UK: Bellstone Training (International) Limited.

Chappe N 2013. Compulsory Non-binding ADR. From http://crese.univ-fcomte.fr/WP-2013-07.pdf. (Retrieved on February 6, 2014).

Cheldelin S 2003. Mediation and arbitration Conflict: From analysis to intervention, Biddles Ltd, London, UK.

Clarke SH, Ellen E D, McCormick K 1995. Court-Ordered Civil Case Mediation in North Carolina: An Evaluation of Its Effects, Prepared for The North Carolina Administrative Office of the Courts. Chapel Hill, NC: State Justice Institute, Institute of Government, University of North Carolina at Chapel Hill.

CLEP 2008. Commission on Legal Empowerment of the Poor. Making the Law Work for Everyone: Working Group Reports. From http://books.google.co.za/books?hl=en\&lr=\&id=0qztitkee_wc\&oi=fnd\&pg=pa1\&dq= ieylrdtg10\&sig=5mylo7v6nduch96komapv2csbbe\#v=onepage\&q\&f=false. (Retrieved on April 11, 2013).

Coben JR, Thompson PN 2006. Disputing Irony: A Systematic Look at Litigation about Mediation. Harvard Negotiation Law Review, 11:43-57.

Cohen AJ 2006. Debating the Globalization of U.S. Mediation: Politics, Power, and Practice in Nepal. Harvard Negotiation Law Review, 11:295-309.

CPR 1993. Center for Public Resources/CPR Legal Program. 1993. Judge's Desk book on Court ADR. New York: Federal Judicial 
Center.p 31.

CPR 1993. CPR Institute for Dispute Resolution, The ABCs of ADR: A Dispute Resolution Glossary, Centre for Public Resources/CPR Legal Program. Alternatives, 13(11): 147-151.

Dani S 2005. Exploring transactions between supply chain entities: a psychological study of buyer-supplier relationships. From https://dspace.lboro.ac.uk/dspace-jspui/handle/2134/12483. (Retrieved on July 4, 2012).

de Vera C 2004. Arbitrating Harmony: Med-Arb and the Confluence of Culture and Rule of Law in the Resolution of International Commercial Disputes in China. Columbian Journal of Asian Law, 18:149-161.

Devereaux C, Lawrence RZ, Watkins M 2006. From http://books.googleYOtewo3IVG\&sig=aaWDfYf91rOrobC_2OyJuVkPw8Y $\# v=$ onepage\&q\&f=false. (Retrieved on August 11, 2012).

Dey I 2009. On the Margins of Citizenship: Principles of Care and Rights of the Residents of the Ranaghat Women's Home, Nadia District. From http://www.mcrg.ac.in/rw\%20files/rw33/rw33.pdf. (Retrieved on august 26, 2012).

Egemen M, Mohamed AN 2006. Clients' needs, wants and expectations from contractors and approach to the concept of repetitive works in the Northern Cyprus construction market. Building and Environment, 41(5): 602-614.

Fiadjoe A 2013. Alternative dispute resolution: a developing world perspective. Cavendish Publication Ltd, London, UK.

Getman JG 1979. Labor arbitration and dispute resolution. http://www.jstor.org/discover/10.2307/795823?uid=3739256\&uid=2 \&uid=4\&sid=21104029629571. (Retrieved on June 14, 2012).

Gibbons M 2007. A review of employment dispute resolution in Great Britain. From http://mail.aryme.com/docs/adr/2-2-1113/arbitrajelaboral-gibbons-2007-uk-gibbons-employment-adr-report.pdf. (Retrieved on July 22, 2012).

Golub S 2003. Non-state justice systems in Bangladesh and the Philippines. From http://gsdrc.org/docs/open/DS34.pdf. (Retrieved on August 16, 2012).

Goresh M A 2008. Paving the Road to a More Free World: ADR as Sustainable Development - A Look at Bangladesh. Pepperdine Dispute Resolution Law Journal, 9:251-264.

Harris F, McCaffer R 2013. Modern construction management. Sussex UK: John Wiley and Sons Ltd.

Hensler DR 2003. Our Courts, Ourselves: How the Alternative Dispute Resolution Movement Is Re-Shaping Our Legal System. Pennsylvania State Law Review, 108:165-179.

Hollander-Blumoff R, Tyler TR 2011. Procedural Justice and the Rule of Law: Fostering Legitimacy in Alternative Dispute Resolution. From http://heinonline.org/HOL/LandingPage?handle=hein.journals/jdisres2011\&div=4\&id=\&page=. (Retrieved on March 24, 2013).

lacobucci D, Churchill G 2009. Marketing research: methodological foundations. Ohio, USA: South Western Cengage Learning.

Iwai N 1991. Alternative Dispute Resolution in Court: The Japanese Experience, Journal on Dispute Resolution, 6:201-216.

Jacobson C, Choi SO 2008. Success factors: public works and public-private partnerships. From http://scholar.google.co.za/scholar?q=\&btnG=\&hl=en\&as_sdt=0\%2C5. (Retrieved on March 19, 2013).

Janicke PM 2002. Maybe We Shouldn't Arbitrate: Some Aspects of the Risk/Benefit Calculus of Agreeing to Binding Arbitration of Patent Disputes. Houson Law Review, 39:693-707.

Jannadia MQ, Assaf S, Bubshait AA, Naji A 2000. Contractual methods for dispute avoidance and resolution (DAR), International Journal of Project Management, 18(1):41-49.

Jardine E 1996. Alternative Dispute Resolution in the Japanese Court System. From http://scholar.google.co.za/scholar?q=jardine++e+ $=\& h l=e n \& a s \_s d t=0 \% 2 c 5$. (Retrieved on January 26,2012 ).

Justice $D$ 2006. How informal justice systems can contribute. From http://ru.unrol.org/files/undp\%20doingjusticeewawojkowska130307.pdf. (Retrieved on May 24, 2012).

Kassebaum G 1989. ADR in India: The Lok Adalat as an Alternative to Court Litigation of Personal Injury and Criminal Cases in South India. Working Paper Series 1989-5. Honolulu: University of Hawaii at Manoa, Program on Conflict Resolution (PCR).

Kotze SJ 2012. Social diversity in an engineering workplace: a conflict resolution perspective. From http://dspace.nmmu.ac.za:8080/xmlui/handle/10948/1638. (Retrieved on May 13, 2014).

Leon JAR 2005. Why Further Development of ADR in Latin America Makes Sense: The Venezuelan Model. From http://heinonline.org/HOL/LandingPage?handle=hein.journals/jdisres2005\&div=22\&id=\&page=. (Retrieved on September 16, 2013).

Lytton T, Centeno Rivas S 1998. 1998. La Resolución de los Conflictos en Nicaragua." In DPK Publication (William Davis, ed.).

McEwen CA 1998. Managing Coporate Disputing: Overcoming Barriers to the Effective Use of Mediation for Reducing the Cost and Time of Litigation. Ohio State Journal On Dispute Resolution, 14:1-14.

McFarland D 2004. Access to justice. Oxford, UK:Oxford University Press.

McGillis D 1997. Community Mediation Programs: Developments and Challenges.

Menkel-Meadow C 2001. Ethics Issues in Arbitration and Related Dispute Resolution Processes: What's Happening and What's Not. University of Miami Law Review. 56:949-961.

Mitchell JK, Devine N, Jagger K 2014. A contextual model of natural hazard. From http://www.jstor.org/discover /10.2307/215114?uid=3739256\&uid=3738032\&uid=2\&uid=4\&sid=21104440805057. (Retrieved on July 19, July 4, 2014).

Mittelman J 2010. Hyperconflict: globalization and insecurity. Stanford University Press: California, USA.

Moore C and Santosa M A 1995. Developing Appropriate Environmental Conflict Management Procedures in Indonesia: Integrating Traditional and New Approaches, Cultural Survival Quarterly, 3:23-29.

Moore CW 2014. The mediation process: Practical strategies for resolving conflict. Califortnia, USA: John Wiley's \&Sons. 
Muralidhar S 2005. Legal aid practices: comparative perspectives. Obiter, 2005. 26(2):261-284.

Onyema E 2013. The Multi-door Court House (MDC) Scheme in Nigeria: A case study of the Lagos MDC. Apogee Journal of Business, Property \& Constitutional Law, 2 (7): 96-130.

Osi C 2008. Understanding Indigenous Dispute Resolution Processes and Western Alternative Dispute Resolution, Cultivating Culturally Appropriate Methods in Lieu of Litigation. Cardozo Journal of Conflict Resolution, 10:163-179.

Othman WH 1996. Community Mediation in Malaysia: A Pilot Program for the Department of National Unity in eds. Fred E. Jandt and Paul B. Pedersen, Constructive Conflict Management: Asia- Pacific Cases, pp. 29-42. Thousand Oaks, London and New Delhi: Sage Publications.

Ozorhon B, Abbott C, Aouad G, Powell J 2010. Innovation in construction: A project life cycle approach. From http://www.salford.ac.uk/_data/assets/pdf_file/0003/297228/SCRIResearchReport4Innovation.pdf. (Retrieved on June 4, 2013).

Porter K, Smith P, Fagg R 2007. Leadership and management for HR professionals. Oxford, UK: Butterworth-Heinemann.

Pretorius P 1993. Dispute Resolution. Cape Town, South Africa: Juta \& Co. Ltd.

Pruitt DG 2005. Escalation Readiness for Negotiation and Third-Party Functions. Escalation and negotiation in international conflicts. Cambridge University Press, Cambridge, USA.

Reilly MT, Mackenzie DL 1999. ADR in the Corporate Environment: A Practical Guide for Designing Alternative Dispute Resolution Systems. C New York, USA:CH Canadian Ltd.

Riskin LL 1997. Understanding mediators' orientations, strategies, and techniques: A grid for the perplexed. From http://papers.ssrn.com/sol3/papers.cfm?abstract_id=1506684. (Retrieved on August 22, 2012).

Roberts S, Palmer M 2005 . Dispute processes: ADR and the primary forms of decision-making. Cambridge, UK:Cambridge University Press.

Rosch J 1987. Institutionalizing Mediation: The Evolution of the Civil Liberties Bureau in Japan, Law and Society Review, 21(2): 243-266.

Sai-On C, Suen $\mathrm{HCH}$ 2002. A multi-attribute utility model for dispute resolution strategy selection. Construction Management and Economics. 20(7): 557-568.

Salami 2012. Saga of Justice, From http://saharareporters.com/article/justice-salami-saga-\%E2\%80\%93-story-rooster-and-fox-ayoturton downloaded. (Retrieved on October 6, 2012).

Shepard RT 2011. Elements of Modern Court Reform. Industrial Law Review, 45:897 -908.

Schrage M 2013. Serious play: How the world's best companies simulate to innovate. From http://books.google.co =redlq_0hia\&sig=ktkp7mrjfpygox1iiasu_cmfa_w\#v=onepage\&q\&f=false. (Retrieved on January 14, 2014).

Sheppard A 2007. Mandatory rules in international commercial arbitration--an english law perspective. The American Review of International Arbitration, 18:121-134.

Sherman EF 1992. Court-Mandated Alternative Dispute Resolution: What Form of Participation Should Be Required. SMU Law Review, 46:2079-2091.

Sherwyn D 2003. Because It Takes Two: Why Post-Dispute Voluntary Arbitration Programs Will Fail to Fix the Problems Associated with Employment Discrimination Law Adjudication. Berkeley Journal of Employment \& Labour Law, 24:1-15,

Sherwyn DS, Eigen ZJ, Sturman MC 2002. Voluntary Arbitration of Employment Disputes: The Compromise that No One Noticed. From https://www.

\%2fvoluntaryarbitration.pdf\%3ft\%3dchr\%26my_path_info\%3dchr\%252fresearch\%252fworking\%252fvoluntaryarbitration\%252ep df. (Retrieved on January 3, 2012).

Singer L, Lewis M, Houseman A, Singer E 1992. Alternative Dispute Resolution and the Poor - Pat I: What ADR Processes Exist and Why Advocates Should Become Involved. Clearinghouse Review, 26:142-156.

Smith S, Martinez J 2009. Analytic Framework for Dispute Systems Design. Harvard Negotiation Law Review, 14: 123139.

Sowell T 2004. Affirmative action around the world: an empirical study. From http://books.google.co.za/books?hl=en \&lr=\&id=jsir5jhderec\&oi=fnd\&pg=pr7\&dq=in+india+aru4f4_30k\&sig=vtneqwa3l3x1a9aops49izsrapi\#v=onepage\&q\&f=false. (Retrieved on April 11, 2013).

Sternlight JR 2007. In Defense of Mandatory Binding Arbitration (If Imposed on the Company). Nevada Law Journal, 8:82-98.

Stong ES 2009. Some Reflections from the Bench on Alternative Dispute Resolution in Business Bankruptcy Cases. American Bankruptcy Institute Law Review, 17:387-399.

Tarr G 2012. Without Fear Or Favor: Judicial Independence and Judicial Accountability in the States. California, USA: Stanford University Press.

Thompson JD 2011. Organizations in action: Social science bases of administrative theory. Transaction Publishers, New Jersey, USA.

Trinder L, Kellett $\mathrm{J}$ 2007. Fairness, efficiency and effectiveness in court-based dispute resolution schemes in England. From http://lawfam.oxfordjournals.org/content/21/3/323.short. (Retrieved on October 16, 2012).

UNDCTM 2007. The United Nations Office of drugs and crime training manual on Alternative dispute Resolution and restorative justice for Nigerian Judges. From http://scholar.google.co.za/scholar?q= \&btnG=\&hl=en\&as_sdt=0\%2C5. (Retrieved on March 2, 2012).

Van Rooij B 2012. Bringing justice to the poor, bottom-up legal development cooperation. Hague journal on the rule of law, 4(2): 286318.

Wahab AA 2013. Court-annexed and judge-led mediation in civil cases: the Malaysian experience. From. http://vuir.vu.edu.au/24331/. (Retrieved on June 14, 2014).

Watson K 2007.Language, education and ethnicity: Whose rights will prevail in an age of globalisation? International Journal of Educational Development. 27(3): 252-265. 
Welsh NA 2001. Making Deals in Court-Connected Mediation: What's Justice Got To Do with It. Washington University Law Quarterly, 79:787-799.

Welsh NA 2004. Place of Court-Connected Mediation in a Democratic Justice System. Cardozo Journal of Conflict Resolution. 5(2):117129.

Weston M A 2003. Confidentiality's Constitutionality: The Incursion on Judicial Powers to Regulate Party Conduct in Court-Connected Mediation, Harvard Negotiation Law Review, 8: 29-41.

Wetsch S R 2000. Alternative Dispute Resolution - An Introduction for Legal Assistance Attorneys. From http://heinonline.org/HOL/LandingPage?handle=hein.journals/armylaw2000\&div=46\&id=\&page=. (Retrieved on April 1, 2012).

Whitson S L 1992. Neither Fish, Nor Flesh, Nor Good Red Herring' Lok Adalats: An Experiment in Informal Dispute Resolution in India," Hastings International and Comparative Law Review, 15(3): 391-445.

Wissler RL 2004. The effectiveness of court-connected dispute resolution in civil cases. Conflict Resolution Quarterly, 22(1-2): 55-88.

Worawattanamateekul N 1996. Arbitration in Thailand in eds. Fred E. Jandt and Paul B.Pedersen, Constructive Conflict Management: Asia-Pacific Cases, pp. 183-187. Thousand Oaks, London and New Delhi: Sage Publications.

Yates JK, Epstein A 2006. Avoiding and minimizing construction delay claim disputes in relational contracting. Journal of Professional Issues in Engineering, 132(2): 168-179.

Zimmer M 2011. Overview of Alternative Dispute Resolution: A Primer for Judges and Administrators. From https://www.iacajournal.org/index.php/ijca/article/view/69. (Retrieved on April 19, 2013). 